\title{
EVALUASI SISTEM PENGENDALIAN MANAJEMEN UNTUK MENINGKATKAN KINERJA MANAJER PENJUALAN PADA TOKO BAPAK WALUYO TULUNGAGUNG
}

\author{
Dhanang Tias Anggoro, Rulin Yunestri, Shafirah Nurlita Chaniago \\ [Program Studi Akuntansi, Fakultas Ekonomi, Universitas Tulungagung]
}

\begin{abstract}
Health in the store body is one factor to maintain the company, which includes the development of a control system where control is also one of the basic functions of management. The object of the research is the shop of Mr. Waluyo Tulungagung. This study aims to determine the state of the existing sales control system in the store, research and try to find alternative solutions to existing problems in order to be a comparison to improve the performance of sales managers at Mr. Waluyo Tulungagung's shop by collecting data using primary and secondary data. The results of the study explain that the management control process has been well proven, the program implementation refers to the previous plan, budget preparation, implementation or measurement is carried out well to the evaluation carried out from each division so that it increases from year to year. to year. The sales manager performs the control system well, including by taking persuasive approaches to the employees under him or by giving rewards to employees who achieve targets. In the sales, implementation or measurement section, the use of on-line network systems between divisions within the Store.
\end{abstract}

Keywords: evaluation, control system management, performance sales manager.

\section{ABSTRAK}

Penyehatan dalam tubuh Toko merupakan salah satu faktor untuk mempertahankan perusaahan, yang diantaranya yaitu mengevaluasi sistem pengendalian manajemen dimana pengendalian juga merupakan salah satu fungsi dasar dari manajemen. Objek dalam penelitian adalah pada Toko Bapak Waluyo Tulungagung. Penelitian ini bertujuan untuk mengetahui keadaan sistem pengendalian manajemen penjualan yang ada dalam Toko, mengevaluasi dan mencoba memberi alternatif pemecahan masalah yang ada guna menjadi sebuah bahan perbandingan untuk meningkatkan kinerja manajer penjualan pada Toko Bapak Waluyo Tulungagung dengan pengumpulan data menggunakan data primer dan sekunder. Hasil penelitian menjelaskan bahwa proses sistem pengendalian manajemen sudah baik terbukti dengan pendelegasian wewenang dengan baik, pelaksanaan program yang mengacu pada rencana sebelumnya, penyusunan anggaran, pelaksanaan atau pengukuran yang diawasi dengan baik sampai pada evaluasi yang dilakukan dari masing-masing divisi sehingga penjualan meningkat dari tahun ke tahun. Manajer penjualan melakukan sistem kontrol dengan baik diantaranya dengan melakukan pendekatanpendekatan secara persuasif dengan para karyawan dibawahmya maupun memberi penghargaan kepada karyawan yang mencapai target. Pada bagian penjualan, pelaksanaan atau pengukuran, diawasi dengan penggunaan sistem jaringan on-line antar divisi di dalam Toko.

Kata kunci: evaluasi, sistem pengendalian manajemen, kinerja manajer penjualan. 


\section{PENDAHULUAN}

Persaingan antara Toko di era globalisasi akan semakin tajam dan konsekuensi logisnya ada tiga kemungkinan yang akan terjadi yaitu mundur, bertahan atau diam di tempat dan lebih berkembang. Setiap Toko tentunya menjalankan aktivitasnya untuk menghasilkan laba demi mempertahankan kelangsungan Toko. Salah satu upaya pencapaian laba tersebut adalah dengan melakukan aktivitas penjualan, karena penjualan merupakan sumber kehidupan Toko. Meningkatnya laba tergantung pada proses penjualan sementara penjualan tergantung pada bagaimana pengelolaan prodak yang dijual dan dilakukan secara professional untuk menghasilkan laba yang diharapkan dan memberi nilai tambah untuk menjaga kesinambungan usaha pengembangannya.

Toko yang memiliki daya saing juga memerlukan manajemen Toko yang senantiasa memerlukan peningkatan (improvement) terhadap aktivitas yang digunakan untuk menghasilkan produk dan jasa. Selain itu untuk mengefisiensikan dan mengefektifkan kerja dalam Toko, perlu dilakukan pendelegasian tugas dari manajer puncak kepada bawahan. Pada saat Toko bertumbuh, manajemen puncak biasanya menciptakan berbagai wilayah tanggungjawab yang dikenal sebagai pusat pertanggungjawaban, dan menugaskan manajer di bawahnya untuk menangani wilayah tersebut. Untuk mempertahankan sebuah Toko, perlu adanya pemikiran-pemikiran yang lebih kritis dan inovatif dalam memperdayakan sumber dana dan sumber daya sehingga stabilitas Toko lebih terjaga. Informasi-informasi akurat sangat dibutuhkan dalam pengambilan keputusan, sehingga harus didukung dengan penggunaan teknologi yang kini telah semakin canggih. Dan tak kalah penting, penyehatan dalam tubuh Toko salah satu faktor untuk mempertahankan perusaahan, yang diantaranya yaitu mengevaluasi sistem pengendalian manajemen dimana pengendalian juga merupakan salah satu fungsi dasar dari manajemen.

Toko Bapak Waluyo Tulungagung adalah salah satu Toko yang menjual Bahan bangunan dan alat listrik di Kota Tulungagung, tentu tidaklah mudah agar dapat bersaing dan bertahan dengan semakin banyaknya toko yang ada, oleh karena itu penulis tertarik melakukan peninjauan dan penelitian dengan judul "Evaluasi Sistem Pengendalian Manajemen Untuk Meningkatkan Kinerja Manajer Penjualan Pada Toko Bapak Waluyo Tulungagung".

Tujuan penelitian ini adalah untuk mengetahui apakah sistem pengendalian manajemen pada Toko Bapak Waluyo Tulungagung dapat meningkatkan kinerja manajer penjualan 


\section{KAJIAN TEORI}

\section{Konsep Akuntansi}

Akuntansi adalah suatu disiplin ilmu yang menyajikan informasi berupa data-data atau laporan keuangan yang dibutuhkan pihak-pihak yang bekepentingan terkait kondisi keuangan Toko tersebut yang sangat berguna dalam pengambilan keputusan. Horngren dan Harrison (2007:4) menyatakan bahwa akuntansi adalah sistem informasi yang mengukur aktivitas bisnis, memproses data menjadi laporan dan mengkomunikasikan hasilnya kepada para pengambil keputusan.

\section{Akuntansi Manajemen}

Hansen, Mowen (2007:6) mendefinisikan akuntansi manajemen sebagai suatu proses pengidetifikasikan, pengukuran, pengakumulasian, penganalisaan, penyiapan, penginterprestasian dan pengkomunikasian informasi finansial organisasi serta untuk menjamin bahwa sumber daya digunakan secara tepat dan akuntabel. Akuntansi sebagai suatu tipe informasi, informasi akuntansi manajemen diperlukan oleh manajemen untuk melaksanakan dua fungsi pokok manajemen, yaitu perencanaan dan pengendalian aktivitas Toko. Informasi akuntansi manajemen ini dihasilkan oleh sistem pengelolahan informasi keuangan yang disebut akuntansi manajemen.

\section{Sistem Pengendalian Manajemen}

Sistem pengendalian manajemen adalah sistem yang digunakan oleh manajemen untuk mempengaruhi para anggota organisasinya agar mengimplemenatsikan startegi-strategi organisasi secara efisein dan efektif dalam rangka mencapai tujuan organisasi. Sumarsan (2013:4) menjelaskan sistem pengendalian manajemen merupakan suatu rangkaian tindakan dan aktifitas yang terjadi pada seluruh kegiatan organisasi dan berjalan secara terus menerus. Pengendalian manajemen bukanlah suatu sistem terpisah dalam suatu organisasi, melainkan harus dianggap sebagai bagian penting dari setiap sistem yang dipakai manajemen untuk mengatur dan mengarahkan kegiatannya. Fungsi manajemen menurut Terry yang dikutip oleh Herujito (2006:18) bahwa fungsi manajemen menjadi empat fungsi yang disingkat dengan POAC yaitu planing atau merencanakan, organizing atau menyusun, actuating atau pelaksanaan dan controling atau mengawasi.

\section{Unsur-unsur Sistem Pengendalian Manajemen}

Suatu sistem pengendalian manajemen yang dapat diandalkan (reliable) harus memenuhi unsur-unsur berikut (Sumarsan, 2013:9):

a. Keahlian karyawan sesuai dengan tanggung jawabnya.

b. Pemisahan tugas

c. Sistem pemberian wewenang, tujuan dan teknik serta pengawasan yang wajar untuk mengadakan pengendalian atas harta, utang penerimaan dan pengeluaran.. 
d. Pengendalian terhadap penggunaan harta dan dokumen serta formulir yang penting.

e. Periksa fisik harta dengan catatan-catatan harta dan utang, atau yang benar- benar ada, dan mengadakan tindakan koreksi jika dijumpai adanya perbedaan.

\section{Struktur Sistem Pengendalian Manajemen}

Struktur merupakan bagian dari sistem pengendalian manajemen., yang berpusat pada bermacam- macam jenis pusat pertanggungjawaban. Pusat pertanggungjawaban adalah unit organisasi yang dipimpin oleh seorang manajer yang bertanggung jawab. Setiap pusat pertanggungjawaban mempunyai masukan dan keluaran. Pada dasarnya terdapat empat jenis pusat pertanggungjawaban menurut Sumarsan (2013), yaitu sebagai berikut:

1. Pusat Biaya (cost center)

2. Pusat Pendapatan (revenue center)

3. Pusat Laba (profit center)

4. Pusat Investasi (investement center)

\section{Proses Sistem Pengendalian Manajemen}

Langkah-langkah proses sistem pengendalian manajemen adalah sebagai berikut:

1. Perencanaan Strategis (penyusunan program)

2. Penyusunan Anggaran (penganggaran)

3. Pelaksanaan dan pengukuran

4. Analisis dan pelaporan prestasi

\section{Konsep Kinerja}

Kinerja berasal dari bahasa job performance atau actual perpormance (prestasi kerja atau prestasi sesungguhnya yang dicapai oleh seseorang atau suatu institusi). Kamus bahasa Indonesia. Menurut Mangkunegara kinerja karyawan (prestasi kerja) adalah hasil kerja secara kualitas dan kuantitas yang dicapai oleh seseorang karyawan dalam melaksanakan tugasnya sesuai dengan tanggung jawab yang diberikan kepadanya (Mangkunegara, 2007:9) sedangkan Wibowo (2007:7) menjelaskan kinerja merupakan hasil pekerjaan yang mempunyai hubungan kuat dengan tujuan strategis organisasi, kepuasan konsumen dan memberikan kontribusi ekonomi

\section{Faktor-Faktor yang Mempengaruhi Kinerja}

Aparatur dalam pencapaian kinerja harus memiliki kemampuan dan motivasi kerja. Kemampuan yang dimiliki aparatur dapat berupa kecerdasan ataupun bakat. Motivasi yang dimiliki aparatur dilihat melalui sikap dan situasi kerja yang kondusif, karena hal ini akan berhubungan dengan pencapaian prestasi kerja atau kinerja aparatur pada lingkungan

\section{Penjualan}

Mulyadi (2008:160) penjualan adalah Suatu kegiatan yang terdiri dari transaksi penjualan barang atau jasa, secara kredit maupun tunai sedangkan Swastha (2005:403) 
menjelaskan penjualan adalah interaksi antara individu saling bertemu muka yang ditujukan untuk menciptakan, memperbaiki, menguasai atau mempertahankan hubungan pertukaran sehingga menguntungkan bagi pihak lain.

\section{Tujuan Penjualan}

Kemampuan Toko dalam menjual produknya menentukan keberhasilan dalam mencari keuntungan, apabila Toko tidak mampu menjual maka Toko akan mengalami kerugian. Swastha (2005:404) menjelaskan tujuan umum penjualan dalam Toko sebagai berikut:

1) Mencapai volume penjualan

2) Mendapatkan laba tertentu

3) Menunjang pertumbuhan Toko

\section{Faktor-Faktor yang Mempengaruhi Penjualan}

Swastha (2005:405) mengemukakan faktor-faktor yang mempengaruhi penjualan sebagai berikut:

1) Kondisi dan Kemampuan Penjual

2) Kondisi Pasar

3) Modal

4) Kondisi Organisasi Toko

5) Faktor-faktor lain seperti periklanan, peragaan, kampanye, dan pemberian hadiah sering mempengaruhi penjualan karena diharapkan dengan adanya faktor-faktor tersebut pembeli akan kembali membeli lagi barang yang sama.

\section{Macam Macam Tujuan Perusahaan}

Pada umumnya perusahaan tidak hanya mempunyai tujuan tunggal, tetapi mempunyai beberapa tujuan yang hendak dicapai. Terdapat variasi perbedaan tujuan yang ingin dicapai oleh organisasi bisnis(Prabowo, 2019), diantaranya :

1. Profitabilitas

2. Efisiensi

3. Kepuasan \& Pengembangan Karyawan

4. Kualitas Produk/Jasa

5. Tanggungjawab Sosial \& Nama / Hubungan Baik dengan Masyarakat

6. Market Leader

7. Survival

8. Kemampuan

9. Pelayanan Masyarakat 


\section{METODE PENELITIAN}

\section{Jenis Penelitian}

Jenis penelitian ini adalah deskriptif komparatif yaitu dengan cara mengumpulkan datadata yang dibutuhkan, dianalisis, diinterprestasikan sehingga bisa menggambarkan suatu keadaan yang diamati kemudian dilakukan perbandingan dengan teori yang digunakan untuk menarik kesmpulan.

\section{Tempat dan Waktu Penelitian}

Tempat penelitian dilakukan pada Toko Bapak Waluyo Tulungagung di Desa Jarakan Kecamatan Gondang. Waktu pelaksanaan penelitian dimulai pada tanggal 21 Desember 2021.

\section{Prosedur Penelitian}

Langkah-langkah yang ditempuh dalam penelitian ini adalah sebagai berikut.

1. Mendefinisikan dan merumuskan masalah

2. Melakukan studi kepustakaan, mengacu pada teori yang berlaku dan dapat dicari atau ditemukan pada buku-buku atas penelitian orang lain.

3. Mengumpulan data sesuai kebutuhan terkait penelitian

4. Mengolah dan menyajikan informasi

5. Menganalisis dan menginterprestasikan

6. Membuat kesimpulan

\section{Metode Pengumpulan Data}

Jenis Data

Data yang digunakan adalah data kualitatif sebagai dasar untuk menganalisis sistem pengendalian manajemen kemudian dievaluasi untuk meningkatkan kinerja manajer penjualan.

\section{Sumber Data}

Sumber data yang digunakan dalam penelitian ini yaitu data primer dan sekunder.Data primer adalah data yang diperoleh langsung dari Toko yaitu Toko Bapak Waluyo Tulungagung sebagai objek penelitian. Data sekunder adalah data yang diperoleh dari literature serta referensi yang ada relevansinya dengan penelitian ini.

\section{Teknik Pengumpulan Data}

Teknik pengumpulan data dalam penelitian ini yaitu:

1. Penelitian kepustakaan (library research), yaitu penelitian yang menggunakan data yang diperoleh dari tulisan-tulisan ilmiah yang ada maupun buku-buku literatur lain yang diperlukan sebagai landasan teoritis dalam penelitin ini.

2. Penelitian lapangan (field research), yaitu penelitian yang dilakukan untuk mendapatkan data-data dan informasi yang intern pada Toko yang bersngkutan. Data yang diambil sebagian besar diperoleh dengan teknik pengumpulan sebagai berikut: 
a. Observasi, yaitu teknik pengumpulan data dengan melakukan serangkaian pengamatan langsung terhadap internal auditor.

b. Wawancara, yaitu teknik pengumpulan data dengan melakukan tanya jawab langsung dengan pihak atau bagian-bagian yang berwenang dalam Toko tersebut yang behubungan dengan masalah yang dibahas.

c. Dokumentasi, yaitu pengumpulan data yang diperoleh dari catatan - catatan yang dimiliki Toko. Teknik ini digunakan untuk memperoleh data tentang dukumen, catatan, dan penerapan sistem pengendalian manajemen.

\section{Metode Analisis Data}

Metode analisis data penelitian ini yaitu dekrpitif dan komparatif. Metode deskriptif, yaitu dengan terlebih dahulu mengumpulkan data dari hasil penelitian untuk diklasifikasikan, dianalisis dan diinterpretasikan sehingga dapat memberikan gambaran yang jelas tentang keadaan yang ditulis.Metode komparatif, yaitu suatu metode analisis yang dilakukan dengan membandingkan teori-teori dengan praktek di dalam Toko, kemudian mengambil kesimpulankesimpulan dan selanjutnya memberikan saran-saran dari hasil perbandingan tersebut

\section{HASIL PENELITIAN DAN PEMBAHASAN}

\section{Sistem Pengendalian Manajemen Pada Toko Bapak Waluyo Tulungagung.}

\section{Perencanaan Strategis}

Manajer menganalisis situasi lingkungan bisnis dan persaingan dimasa depan dan kemudian menyusun langkah-langkah strategik untuk memasuki lingkungan bisnis dan persaingan sebagaimana yang diperkirakan sebelumnya. Dalam perencanaan tersebut mulai dipertimbangkan berbagai alternatif untuk menghadapi masa depan, karena jangka waktu yang panjang memberikan kesempatan untuk dilakukannya evaluasi terhadap berbagai alternatif tersebut. Perecanaan strategi di Toko Bapak Waluyo Tulungagung disusun secara terpisah sesuai dengan unit bisnis masing-masing.

Proses menyusunan program kerja Toko diperlukan informasi tentang jumlah investasi yang dilakukan, pendapatan (revenues), dan juga total biaya (cost) yang dikeluarkan Toko. Penyusunan program kerja dilakukan oleh Toko yaitu berdasarkan masing-masing divisi dalam struktur Toko. Program disusun setiap tahun dua kali atau per semester.

\section{Penyusunan Anggaran}

Toko Bapak Waluyo Tulungagung menerapkan sistem anggaran yang ditetapkan Toko secara berkala menurut kondisi dan pengalaman masa lalu dan intuisi dari manajemen. Anggaran sebuah proram diajukan oleh masing- masing divisi yang diajukan kepada bagian umum dan dikeluarkan oleh bagian administrasi keuangan. Anggaran yang telah disahkan tersebut kemudian akan digunakan sebagai alat pengendalian kegiatan operasi Toko oleh manajemen 
puncak dan para manajer pusat pertanggungjawaban akan dievaluasi dan dianalisa prestasi aktualnya berdasarkan anggaran tersebut. Dalam melakukan pembiayaan pada setiap divisi dibutuhkan kerjasama dengan bagian umum dan administrasi keuangan, karena semua pembiayaan yang terjadi di Toko Bapak Waluyo Tulungagung melalui proses dibagian umum kemudian dikeluarkan atau dilunasi melalui bagian administarasi dan keuangan.

\section{Pelaksanaan dan Pengukuran}

Rencana strategi yang sudah disepakati yang kemudian menjadi acuan bagi setiap divisi dalam pelaksanaan program, masing-masing kepala bagian menyampaikan strategi - strategi tersebut untuk segera direalisasikan. Dalam tahap ini, manajer berfungsi untuk mengontrol para karyawan dalam menjalankan tugas sesuai dengan program yang telah direncanakan sebelumnya. Kabag administrasi dan keuangan yang membawahi tiga kepala seksi yaitu kasie keuangan, kasie IT, dan kasie pembukuan. Serta kabag umum yang membawahi dua kepala seksi yaitu personalia dan umum. Dalam sehari supervisor yang dibawah kabag penjualan yang bertugas mengontrol para salesman, melakukan meeting setiap hari dipagi hari guna mengkomunikasikan strategi-strategi penjualan.

\section{Evaluasi dan Proyeksi}

Toko Bapak Waluyo Tulungagung dalam pengevaluasian program, tiap bagian dan divisi wajib memasukkan laporan pertanggungjawaban atau hasil-hasil kerja yang telah dicapai, selanjutnya laporan tersebut disampaikan kepada bagian admin. Admin dalam hal ini memiliki tugas untuk menginput data-data atau laporan dari hasil kerja tiap-tiap divisi setiap harinya. Khusus bagian penjualan, supervisor dengan masing-masing salesman melakukan meeting setiap hari diwaktu soreh untuk evaluasi. Dengan melakukan evaluasi, dapat memproyeksi kelemahan atau yang menjadi kekurangan serta masalah yang dihadapi dari setiap salesman sehingga bisa langsung ditemukan solusi.

Bagian admin dan keuangan membuat laporan pada akhir semester yang berisikan semua pendapatan, pembiayaan, beban, pajak maupun aktiva Toko Bapak Waluyo Tulungagung, untuk menilai dan mengevaluasi kinerja karyawan. Laporan tersebut juga akan menjadi proyeksi atau landasan dalam pernecanaan strategis Toko Bapak Waluyo Tulungagung semester berikut. Bagian umum membuat laporan akhir tahun yang berisikan semua pendapatan, hutang, pembiayaan, beban, pajak maupun aktiva Toko dalam periode satu tahun berjalan. Laporan ini akan menjadi dasar atau acuan dalam memproyeksikan program di tahun berikutnya.

\section{Kinerja Manajer Penjualan}

Manejer penjualan Toko Bapak Waluyo Tulungagung dalam meningkatkan penjualan menggunakan beberapa pendekatan dengan divisi-divisi dibawahnya seperti pendekatan komisi, rapat penjualan, pemberian penghargaan dan kesempatan berlibur yang dibiayai oleh Toko. Setiap sales memiliki klasifikasi dalam target penjualan. Untuk sales yang telah bekerja selama 
dua tahun ke atas dikategorikan sebagai sales senior dan diberi target lima sampai enam unit kendaraan. Sementara untuk sales junior yang kurang lebih dua tahun ke bawah, memiliki target penjualan tiga unit kendaraan. Target penjualan dilakukan agar bisa memacu semangat dalam melakukan aktivitas penjualan.

\section{Pembahasan}

Toko memiliki sisi kekuatan dari struktur organisasi yang dimiliki. Struktur fungsional yang dimiliki Toko Bapak Waluyo Tulungagung begitu kompleks, yaitu dibuktikan dengan lebih spesifiknya penjabaran jabatan sehingga pembagian wewenang dan tanggung jawab masingmasing bagian juga jelas. Kekuatan sistem pengendalian manajemen lain Toko Bapak Waluyo Tulungagung terletak pada jejaring organisasi yang terpadu antara Toko Bapak Waluyo dengan beberapa Toko yang ada di Tulungagung.

\section{Evaluasi Proses Sistem Pengendalian Manajemen}

\section{Perencanaan Strategis}

Perencanaan strategis diperlukan untuk menjadi tolak ukur dalam menjalankan suatu organisasi. Perencanaan strategis/penyusunan program pada Toko Bapak Waluyo Tulungagung yang dilakukan melalui rapat umum yang dihadiri oleh manajer-manajer. Hasil rapat tersebut kemudian di sosialisasikan kepada tiap-tiap divisi masing-masing untuk dijalankan sesuai strategi-strategi yang telah ditetapkan. Menurut penulis perencanaan strategis yang diterapkan Toko Bapak Waluyo Tulungagung sudah baik dengan merangkul semua partisipasi baik dari level top management dan para anggota.

\section{Penyusunan Anggaran}

Penyusunan anggaran dilaksanakan setelah selesai penyusunan program atau perencanaan strategis. Artinya, anggaran disesuaikan dengan program yang memiliki strategistrategi yang telah disepakati. Untuk organisasi secara keseluruhan organisasi memiliki anggaran masing-masing yang dibedakan berdasarkan pusat pertaggungjawaban. Sistem penganggaran yang dilakukan oleh Toko ini diberikan tanggungjawab kepada divisi masing-masing dengan pengawasan manajer tiap divisi, kemudian diajukan pada bagian umum untuk di input dan diproses selanjutnya dana program disetujui akan dikeluarkan oleh bagian keuangan.

\section{Pelaksanaan dan Pengukuran}

Pelaksanaan program yang telah di tetapkan sesuai rencana dan anggaran yang telah ditetapkan dilakukan setelah penyusunan anggaran. Sejauhmana program-program yang sudah disosialisasikan dapat diterapkan oleh seluruh karyawan Toko selaku penggerak usaha. Toko Bapak Waluyo Tulungagung menggunakan sistem komputerisasi dalam rangka pengawasan disetiap bidang. Pada bagian penjualan, pelaksanaan atau pengukuran, diawasi dengan penggunaan sistem jaringan on-line antar divisi di dalam Toko.

\section{Evaluasi dan Proyeksi}


Pada tahap evaluasi, di setiap divisi bagian penjualan dilakukan setiap hari guna memprediksi hasil kinerja karyawan dan mencari solusi bila ditemui hambatan ataupun masalah. Contoh bila terjadi komplain konsumen atas kendaraan yang dibelinya, konsumen dapat mengadu dibagian CRC. Pada hari itu juga saat evaluasi crc melaporkannya sehingga segera dapat diketahui apa yang menjadi kendala atau kesalahan sehingga segera mecari alternative solusi.

\section{Kinerja Manajer Penjualan}

Kabag penjualan sebagai penanggungjawab penuh dalam penjualan, juga sudah melakukan tugasnya dengan baik. Dalam rangka peningkatan penjualan, kabag penjualan harus menjadi panutan dan bersikap low profile kepada setiap divisinya. Kebersamaan dan merasa saling memiliki harus ditanamknan sehingga dapat mendorong semangat untuk tidak bermalasmalasan. Pendekatan persuasif secara personal dengan bawahannya juga harus dilakukan sebagai bentuk pendekatan emosional guna mengetahui sedikit tidaknya sifat dan perilaku karyawan.

Distribusi penghargaan juga tidak hanya diberikan pada manajemen puncak sebagai perumus strategi bisnis organisasi, namun setiap karyawan yang memberikan kinerja terbaik pada Toko berhak untuk memperoleh penghargaan dari Toko. Penghargaan berupa insentif, tour yang dibiayai yang diberikan Toko kepada karyawan yang mencapai target penjualan juga menjadi salah satu motivasi. Untuk itu manajer juga harus teliti dalam pengontrolan kinerja divisi dibawahnya. Pergeseran paradigma mengenai sistem penilaian kinerja menjadi lebih komprehensif sehingga memotivasi eksekutif untuk memikirkan kelangsungan hidup organisasi dalam jangka panjang. Hal ini yang diterapkan dalam sistem penghargaan Toko Bapak Waluyo Tulungagung dengan berbasis kepada tanggung jawab masing-masing personel untuk mencapai tujuan organisasi secara keseluruhan (responsibility-based organization). Menurut hemat penulis sistem pengendalian manajemen yang diterapkan Toko Bapak Waluyo Tulungagung sudah dapat meningkatkan kinerja manajer penjualan. 


\section{KESIMPULAN DAN SARAN}

\section{A. Kesimpulan}

Setelah menganalisis dan mengevaluasi sistem pengendalian manajemen untuk meningkatkan kinerja manajer penjualan Toko Bapak Waluyo Tulungagung maka penulis dapat mengambil kesimpulan, diantaranya:

1. Sistem pengendalian manajemen pada Toko Bapak Waluyo Tulungagung pada dasarnya sudah baik karena jelasnya pendelegasian wewenang pada tiap-tiap manajer-manajer maupun divisi sehingga dapat meningkatkan kinerja manajer penjualan Kerjasama yang terjalin antara manajer dan bawahan juga terjaga dengan baik sehingga masing-masing mengambil bagian dalam pengendalian manajemen.

2. Sistem pengendalian manajemen yang baik dibuktikan juga dengan meningkatnya penjualan dari tahun ketahun yang membuat Toko semakin berkembang.

3. Toko Bapak Waluyo Tulungagung memberikan wewenang kepada manajermanajernya untuk merencanakan strategi-strateginya, pendapatan-pendapatan atau biaya. Akan tetapi untuk pelaporan hanya ditugaskan kepada bagian admin saja, hal ini yang membuat informasi akuntansi pertanggungjawaban Toko Bapak Waluyo Tulungagung kurang begitu efektif.

4. Struktur organisasi Toko Bapak Waluyo Tulungagung berbentuk unit bisnis dimana ada otoritas dan tanggung jawab yang jelas antara superior dan sub ordinat.

\section{B. Saran}

Penulis memberikan saran sebagai berikut:

1. Kepada karyawan agar dapat terus mempertahankan kinerja dan produktivitasnya untuk kemajuan tokonya.

2. Perlu diadakannya peningkatan kualitas sumber daya manusia, baik pelatihanpelatihan maupun pendekatan penghargaan bisa juga ditambahkan dengan beasiswa ke jenjang studi selanjutnya. 


\section{DAFTAR PUSTAKA}

Hansen, Mowen. 2007. Akuntansi Manajemen. Diterjemahkan oleh Hermawan, Ancella A. Erlangga. Jakarta.

Herujito, M. Yayat. 2006. Dasar - dasar Manajemen. Grasindo. Jakarta.

Horngren, Charles dan Harrison, Walter Jr. 2007. Akuntansi Jilid I. Edisi Tujuh. Jakarta.

Mangkunegara, Prabu. 2007. Manajemen Sumber Daya Manusia. Cetakan Ketujuh. PT. Remaja Rosdakarya. Bandung.

Mulyadi. 2008. Akuntansi manajemen, Konsep, Manfaat dan Rekayasa. Salemba Empat. Jakarta.

Prabowo, R. G. M. (2019). Manajemen Strategi Penulis: Rachmad Gesah Mukti Prabowo. INARxiv Paper.

Sumarsan, Thomas. 2013. Sistem Pengendalian Manajemen, Konsep, Aplikasi dan Pengukuran Kinerja. Edisi 2. Indeks.

Swastha, Basu. 2005. Manajemen Penjualan. Cetakan keduabelas. Liberty Yogyakarta. Yogyakarta.

Thionardo, Richard. 2012. Evaluasi Peran Sistem Pengendalian Manajemen (SPM) Untuk Meminimalkan Konflik Pada Badan Usaha Keluarga “K” di Tulungangung. ISSN 2302-8203, Vol. 1 No.1 2012, Hal 1- 12.

Wibowo. 2007. Manajemen Kinerja. PT. Rajagrafindo Persada. Jakarta. 